\title{
Challenge and Drivers of Over-Enrollment in the Early Years of Primary School in Uganda
}

\author{
Tara Weatherholt ${ }^{1} \cdot$ Rachel Jordan $^{1} \cdot$ Luis Crouch $^{1} \cdot$ Ed Barnett $^{2}$. \\ Jennifer Pressley ${ }^{1}$
}

Published online: 19 March 2019

(O) The Author(s) 2019

\begin{abstract}
Consistent over-enrollment, together with low official repetition rates, in the early years of school indicates inaccurate reporting of repetition, which may mask the reasons for low primary school completion. Actual repetition rates may be higher and pose issues for teachers through overcrowding of classrooms and issues for governments through inefficient education systems. This research explores repetition rates of students in Primary 1 in Uganda and considers the implications for efficiency and quality of education for the early years of school. The sample comprised 1440 students in Primary 1 classrooms in 120 schools. Interviews were conducted with 1318 caregivers of randomly selected students and 1439 teachers of the same students, and official records from 118 schools were examined to compare age and repetition rates. Findings showed that caregiver- and teacher-reported repetition is much higher than officially reported by schools; that repetition is strongly linked to nonattendance in pre-primary schooling; and that caregivers reported more over-age students, fewer target-age students, and more under-age students than official school records. Policy implications include the need for dialogue around repetition rates and the possible efficiency effects of less-costly, pre-primary education on the total primary schooling cycle.
\end{abstract}

Keywords Pre-primary education · Repetition $\cdot$ Low-income countries $\cdot$ Education efficiency $\cdot$ Early childhood

Tara Weatherholt

tweatherholt@rti.org

1 Division of International Education, RTI International, 3040 East Cornwallis Rd, Research Triangle Park, NC, USA

2 London School of Economics and Political Science (LSE), London, UK 


\section{Résumé}

Les sureffectifs constants associés à de faibles taux officiels de redoublement dans les premières années d'école indiquent que les redoublements sont rapportés de façon inexacte, ce qui peut cacher les raisons du faible taux de réussite à l'école primaire. Les taux réels de redoublement peuvent être plus élevés et poser des problèmes aux enseignants par des salles de classe surchargées, et aux gouvernements par des systèmes d'éducation inefficaces. Cette recherche explore les taux de redoublement chez les élèves de $1^{\mathrm{e}}$ année du primaire en Ouganda et examine les implications pour l'efficacité et la qualité de l'éducation dans les premières années d'école. L'échantillon se compose de 1440 élèves de $1^{\mathrm{e}}$ année du primaire dans 120 écoles. Des entretiens ont été effectués auprès de 1318 éducateurs d'élèves choisis au hasard et de 1439 enseignants des mêmes élèves; par ailleurs, les dossiers officiels de 118 écoles ont été examinés pour comparer les âges et les taux de redoublement. Les résultats montrent que les redoublements signalés par les éducateurs et par les enseignants sont beaucoup plus élevés que ceux signalés officiellement par les écoles; que les redoublements sont fortement liés à la non fréquentation préscolaire; et que, comparativement aux rapports scolaires officiels, les éducateurs signalent plus d'élèves plus âgés que la normale, moins d'élèves de l'âge cible, et plus d'élèves moins âgés que la normale. Les implications pour les politiques incluent la nécessité d'un dialogue sur les taux de redoublement et les effets possibles de l'efficacité d'une éducation préscolaire moins coûteuse sur le cycle complet de la scolarité primaire.

\section{Resumen}

Tasas de sobre cupo consistentes junto con bajas tasas oficiales de repetición en los primeros años de escuela indican un reporte inexacto de repetición, lo cual puede conllevar a ocultar las razones detrás de las bajas tasas de culminación de estudios de primaria. Las tasas de repetición reales podrían ser más altas y acarrear problemas para los profesores por sobrepoblación de los salones de clase y problemas para los gobiernos causados por sistemas educativos ineficientes. Este estudio explora las tasas de repetición de estudios en Primaria 1 en Uganda y considera las implicancias para la eficiencia y calidad de la educación en los primeros años escolares. La muestra incluyó 1440 estudiantes de salones de Primaria 1 en 120 escuelas. Se realizaron entrevistas a 1318 educadores pre-escolares de estudiantes aleatoriamente seleccionados y 1439 profesores de los mismos estudiantes; así mismo, se examinaron registros oficiales de 118 escuelas para comparar edades con tasas de repetición. Los resultados indicaron que la repetición reportada por educadores pre-escolares y profesores es mucho más alta que las reportadas oficialmente por las escuelas; dicha repetición está estrechamente ligada a las bajas tasas de asistencia en la escuela pre-escolar y al hecho de que los educadores de pre-escolar reportan más estudiantes de edad avanzada, menos estudiantes en edades adecuadas y más estudiantes de menor edad que los registros escolares oficiales. Las implicancias políticas incluyen la necesidad de sostener un diálogo acerca de las tasas de repetición y los posibles efectos sobre la eficiencia de programas menos costosos de escolaridad pre-escolar en el ciclo total de escuela primaria. 


\section{Introduction}

In many developing countries, including Uganda, the prioritization of Universal Primary Education (UPE) in the late 1990s led to a significant increase in primary school enrollment. While this progress in expanding access is a cause for celebration, macro-level data from many Education Management Information Systems (EMIS) across countries have consistently shown gross enrollment rates much higher than $100 \%$ in early primary grades, as well as more children enrolled in specific primary grades than there are children of that age in the overall population. Although overenrollment in some countries was expected for several years, as education systems enrolled large numbers of children who had not previously been enrolled in school, high gross enrollment rates for more than 10 years indicates problems in the efficiency of the education systems (Crouch and Merseth 2017). The concept of internal efficiency of education systems (Lockheed and Hanushek 1994) also draws attention to the educational costs per student who may complete any schooling cycle. This is the cost per student per year of education multiplied by the number of grades completed. Less inefficient systems engender concern because of the high use of resources. A likely reason for high enrollment rates in the early grades of school is grade repetition. This is the focus of this research that explores over-enrollment in the first year of primary school in Uganda.

\section{Grade Repetition and Its Consequences}

Repetition has been shown to be an early warning sign of school dropout (Gibbs and Heaton 2014; Sabates et al. 2013). A failure to proceed through schooling at the standard pace is strongly associated with learners dropping out of school even after controlling for socio-economic status (SES) and school quality (Branson et al. 2013). Additionally, repetition is not an efficient way to help struggling students improve their level of attainment (N'tchougan-Sonou 2001; Smith 1989). Data from the Southern and Eastern Africa Consortium for Monitoring Educational Quality for 10 low- and middle-income countries showed that, on average, repeaters scored lower on reading tests than non-repeaters (Smith and Barrett 2010). In addition to being negatively correlated to reading and mathematics achievement ( $\mathrm{Yu}$ and Thomas 2008), the negative effects of repetition are compounded when multiple repeaters perform worse than students who only repeat once (Van der Berg 2008).

Repetition and dropout are typically cited as leading causes of waste in educational resources (Bernard et al. 2007; Kabay 2016). Furthermore, the higher schooling cycle costs per student and overcrowded classrooms can result in lower quality of education (Crouch and Merseth 2017; Mosteller 1995). When children at various developmental stages and ability levels are included in a single classroom, a wider range of instructional strategies will be required. In this sense, "repetition may merely lead to more repetition instead of better learning" (Amadio 1996).

Repetition trends have been studied for decades to better understand the implications of the persistence and magnitude of repetition (Amadio 1996). Data from 1990 for 84 countries showed a total of almost 35.6 million cases of repetition in primary 
school (Amadio 1996), with enrollment rates steadily increasing most notably in sub-Saharan Africa, where the total number of estimated primary school repeaters (11.4 million) in 2010 made up nearly one-third of the global total (UNESCO Institute for Statistics 2012). Yet, due to inaccurate reporting and unreliable methods of record-keeping, the available data often fail to reflect the scale of the problem. Repeaters have sometimes been mistakenly counted as dropouts or new entrants (Cuadra and Ewert 1987; Klein and Ribeiro 1991) and repetition as reported by parents and teachers is sometimes four to five times higher than what is reported in EMIS, as documented in Nicaragua in the 1990s (Gargiulo and Crouch 1994). One potential sign that repetition rates are higher than officially reported rates are the high grade-specific gross enrollment rates in Primary 1 and Primary 2, with a drop off after Primary 1. Official gross intake ratios into Primary 1 have also persisted well above 100\% for over 10 years (Crouch and Merseth 2017). Crouch and Merseth (2017) argue that this phenomenon may indicate that learners are enrolled in Primary 1 at an inappropriate age or, more importantly, remain there for two or more years, without being reported as repeaters.

One strategy for potentially decreasing repetition is to increase the readiness of children entering the system by expanding access to pre-primary education (Lockheed and Verspoor 1992). Evidence suggests a positive relationship between preprimary education and improved learning outcomes (Lockheed and Verspoor 1992; King and Meyers 1983; Jarmillo and Tietjen 2001; Rao et al. 2014; Reimers 1993). In Nepal, learners who participated in a school readiness intervention repeated Grade 1 at a lower rate than the national average (Bartlett et al. 2004), while longitudinal studies from Argentina (Berlinski et al. 2006) and Burma (Save the Children 2004) found that increased provision or expansion of pre-primary education led to improved retention and academic performance in primary school.

\section{Ugandan Context of Education}

With the introduction of Universal Primary Education in Uganda in 1997, primary school enrollment rose dramatically-from 2.5 million learners in 1996 to 8.3 million in 2015 (Ministry of Education and Sports 2015). Repetition, however, remains a problem for the Ugandan education system. When the population of Ugandan children of the appropriate age is compared to actual enrollment in the corresponding grade, over-enrollment in Primary 1 followed by a noticeable drop off in Primary 2 is evident. The ratios of enrollment to population of appropriate age in Uganda were 1.4 in Primary 1 and 1.1 in Primary 2, according to the most recent data reported by the World Bank (UNESCO Institute for Statistics 2016), and have been even higher in the past, implying an over-enrollment of $40 \%$ in Primary 1, which has persisted for several years.

Data available through the World Bank shows that for the past 10 years, primary school completion rates in Uganda have continued to hover around 50-60\% and the official repetition rate is relatively low at around 5\% and $8 \%$ in recent years for Primary 1 and Primary 2 (UNESCO Institute for Statistics 2016). Other support exists for the possibility of unreported repetition in Uganda. Because of the automatic promotion policy in place in which students progressing to the next grade 
level are mandatory, head teachers may not report true repetition rates in their school out of fear of breaking with policy. Furthermore, schools receive capitation grants in which the amount of support depends on the number of students enrolled, which presents an incentive for head teachers to inflate enrollment numbers (Sandefur and Glassman 2014), possibly through the acceptance of under-age children and then not declaring them as repeaters.

Despite the potential benefits of pre-primary education, official data suggests a gross enrollment ratio for pre-primary education in Uganda that hovers around $10-12 \%$, as indicated from the UNESCO Institute for Statistics. For several decades, there has been wide variation in the types of pre-primary education provided in Uganda, from informal home-based nurseries to private kindergartens (Okuni 2003). Additionally, parents often send their children to school early due to the cost of or distance to a pre-primary program, even with full knowledge that the child might repeat and/or learn less in their first time through Primary 1 (Brunette et al. 2017). The involvement of the Ugandan government in registration of pre-primary programs and accreditation has been sporadic, although greater involvement in policy-making for pre-primary education, curriculum development, and teacher training is somewhat more apparent recently (Ejuu 2012).

\section{Research Questions and Hypotheses}

To better understand the drivers of over-enrollment in Primary 1 in Uganda, this study examines repetition rates reported by caregivers and teachers in comparison with the repetition rates reported through official channels. The study also explores the relationship between repetition and participation in pre-primary education. The research questions and related hypotheses driving the current study are as follows:

1. Are over- and under-age learner enrollments and grade repetition higher when reported by caregivers and teachers than reported in official records? We hypothesize that the proportion of repeaters, and of under-age and over-age pupils enrolled in Primary 1 will be higher according to caregiver and teacher reports than the proportions reported to the Government of Uganda and in school records.

2. To what extent is repetition in Primary 1 serving as a substitute for pre-primary education? We hypothesize that some caregivers may be using access to fee-free Primary 1 in lieu of a relatively more expensive pre-primary option, even when they know this might mean that children will repeat.

3. Are children who are exposed to pre-primary education less likely to repeat, even when controlling for other factors? We hypothesize that children who are exposed to pre-primary education are less likely to repeat Primary 1 . 


\section{Method}

The current study was part of a larger research project examining over-enrollment and repetition issues and a macro-level analysis of efficiency in Ugandan policy and financing in the education sector.

\section{Sampling Frame and Participants}

A stratified sampling process was used to recruit schools and participants into the research. The school information list, including school name, sub-region, district, and number of students, was obtained through official Uganda EMIS data from the most recent year available to when the study was conducted. Ten sub-regions in Uganda acted as strata and districts within sub-regions, and were selected by using a stratified, simple random sampling technique. The number of districts sampled per sub-region depended on the number of districts contained in each sub-region; subregions with more districts made up a larger part of the sample of districts. Five schools were selected from within the sampled districts, using probability proportional to size sampling, from public schools with Primary 1 student enrollment between 20 and 700 students. Finally, 12 students from each school were selected from each stream of Primary 1 included at the school using a randomized process. Thus, the sample of students is representative of students attending government schools in Uganda, ${ }^{1}$ reflecting Ugandan national data on geographic location, as shown below.

The sample comprised 1440 students identified from Primary 1 classrooms in 120 schools across 24 districts. There were 101 schools (84\%) in rural areas (national estimate of the population is $75 \%) ; 7(6 \%)$ in urban areas (national estimate $10 \%$ ); and $12(10 \%)$ in semi-urban areas (national estimate 15\%). From each school, student-level data and school-level data were collected.

Interviews were conducted with 1318 primary caregivers of the randomly selected students, comprised of mothers (41\%), fathers (37\%), and other family member $(22 \%)$ such as grandparents, aunts, and uncles. Interviews were also conducted with the teachers of the same students $(n=1339)$ to contribute to the studentlevel data. Records from 118 schools were reviewed, and head teachers of 115 of the schools visited were interviewed to contribute to the school-level data. It should be noted that although the student sample from the caregiver reports is from a subset of the student sample provided from the school records, the caregiver data on students should be representative of students in Primary 1 classrooms in the respective schools, given the random student sampling procedure.

The sample comprised $50 \%$ girls $(n=716)$ and $50 \%$ boys $(n=723)$. The mean age of students in the sample was 6.9 years. Reports from caregivers indicated that $9 \%$ of students in the sample had a disability, including hearing impairment (3\%), physical impairment (2\%), and visual impairment (1\%). Regarding highest level of

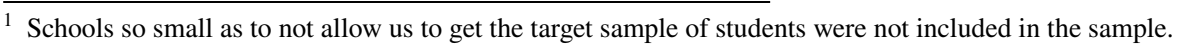


education completed, $62 \%$ of caregivers reported some attendance at primary school and $22 \%$ attended at least some secondary schooling.

\section{Research Ethics}

The study protocol and instruments used in the research were submitted to two Institutional Review Boards (IRBs) for the authors' organization, as well as to the School of Biomedical Sciences Research and Ethics committee (SBS-REC) at Makerere University in Kampala, Uganda, for approval. In line with the guidelines of responsible and ethical research, participants were given a unique code number, and no names were collected. Informed consent was collected from caregivers, teachers, and head teachers. All participants were informed that they could decline participation or discontinue participation at any time.

\section{Survey Design and Procedure}

Survey instruments used in interviews with caregivers and teachers went through a rigorous process of adaptation, translation, pre-testing, and piloting. Surveys were revised based on results from pre-testing, and then piloted in two districts. As the current study used a national sample, the instruments underwent a two-day adaptation workshop with officials from the Ministry of Education and Sports (MoES). The survey instruments were then translated into 13 languages relevant to the districts selected. The caregiver survey was directly administered and included questions about the student's age, primary and pre-primary education enrollment and repetition, as well as caregivers' expectations and knowledge about schooling. Primary 1 teachers were surveyed about each student in the sample, including questions about primary school enrollment and pre-primary education, repetition, and the teacher's expectation of the student's progression into Primary 2. Head teachers were surveyed for information about Primary 1 classrooms, such as the number of streams and any instances of special streams for younger children. All questions in each instrument were multiple choice or closed questions, with the opportunity to also enter unlisted responses ('other') or comments. Not all of the data obtained from the instruments are presented in this paper.

Three types of school records (classroom registers, head teacher registers, and school information from EMIS records) were reviewed at 118 schools for classroom-level information about enrollment age, gender, and repetition. Data collectors recorded from each type of school record the number of students by gender at each age, from 3 to 12 years. If the school records included data on repetition, data collectors also recorded the number of repeaters by gender. School records which did not include data on repetition were omitted from subsequent school-level repetition analysis. Table 1 shows the number and percentage of schools with each school record source. Eighty-one schools had at least two types of school records available, and EMIS forms were most often missing. While one of the paper's main points is that school records of repetition may not align with caregiver and teacher recall of repetition, the data presented here indicate a general issue of the quality of 
Table 1 Schools with classroom-level data

\begin{tabular}{lll}
\hline Source & $\begin{array}{l}\text { No. of schools repre- } \\
\text { sented }\end{array}$ & $\begin{array}{l}\text { Percentage } \\
\text { of schools }\end{array}$ \\
\hline Classroom register & 93 & 77.5 \\
Head teacher records & 74 & 61.7 \\
EMIS records & 63 & 52.5 \\
No records at all & 2 & 1.7 \\
\hline
\end{tabular}

record-keeping in Uganda. Information from all records represents Primary 1-level data, not school-level data.

The research methodology was successfully tested in a large-scale pilot study (Brunette et al. 2017). Data collection occurred over 2 days at each school at the beginning of the third term of the school year in September of 2017. Trained data collectors interviewed the head teacher to determine the number of Primary 1 classrooms and teachers. Primary caregivers of sampled students were invited to the school for an interview. Data collectors then reviewed the available classroom, head teacher, and EMIS records at the school. Teacher interviews about the randomly selected students were conducted at the conclusion of the school day. Invitation letters were sent home to caregivers on the first day of data collection, and interviews with them were conducted on the second day of data collection. A high caregiver response rate was important in order to obtain a reliable age and repetition rate comparison among sources. A participation rate of $92 \%$ was achieved through giving caregivers one day's notice of the interview and a subsidization (approximately UGX 7000 or US \$2) for travel.

\section{Description of Variables Used in the Analyses}

Key variables used in the analyses are described in this section, including information about child age and how under-age, target-age, and over-age for grade were defined, as well as how grade repetition was measured. Questions asked of caregivers and teachers about their expectations of grade repetition for a child and whether a child had participated in a pre-primary year of education are also described.

\section{Age}

Caregivers reported the child's age and date of birth (DOB) to calculate child age at the time of the study. School records may have included either age or DOB. If DOB was recorded, the age was calculated from the year of birth. Age data from caregivers and school records was categorized as under-age, target-age, and over-age for grade as advised by Uganda's official government policy (Education Act of 2008). Under-age for grade consisted of pupils at 5 years or younger; target-age for grade consisted of pupils at 6 and 7 years; over-age for grade consisted of pupils 8 years and older. The percentage of children at each age category for all school records by school was calculated using total number of pupils in each age category in Primary 
1 divided by the total number of pupils in Primary 1 for each respective school. Additionally, the age of the child at the time of enrollment in Primary 1 was also measured through caregiver report.

\section{Repetition}

A child was considered a repeater if the child was attending Primary 1 for the second (or more) consecutive year at the time of the study. Caregivers and teachers were asked "What class did this child attend last year?", and a response of Primary 1 categorized that child as a repeater. Although the MoES officially subscribes to the same definition, anecdotal evidence has suggested that schools may use unofficial repetition whereby young students attend a special stream of Primary 1, where repetition is expected but is not officially counted or reported as repetition. Additionally, caregivers and teachers were asked "Do you expect this child to progress to Primary 2 class next year?" to determine non-repetition expectations of caregivers and teachers.

\section{Pre-primary (Nursery) Participation}

For the purposes of our study, pre-primary education included formal private nursery, home-based nursery, community-based nursery, and daycare centers. Pre-primary education did not include attending a special stream of Primary 1 for younger students. Both caregivers and teachers were asked "Did this child attend nursery?" Data collectors were trained to discuss the answer with caregivers and teachers in order to ensure that the same definition and clarification was used across the interviews. Official pre-primary enrollment data for Uganda comes from reports by registered nursery centers and the national EMIS.

In addition to the above variables, a measure of caregiver SES was also included in the analyses related to Research Question 3 as to whether children who had completed a pre-primary year were less likely to repeat Primary 1. This measure of caregiver SES was essentially a wealth index and created using a Principal Components Analysis of responses to seven questions regarding household items (e.g., ownership of vehicles and electronic devices). In order to create simple categories by which to compare other outcomes, and in accordance with well-established methodology (Filmer and Pritchett 2001), this index was then divided into quartiles to represent Low, Mid-Low, Mid-High, and High SES groups within the sample. Therefore, the SES values of the students in the sample were, by construction, relatively evenly distributed across low (25.8\%), mid-low (25.7\%), mid-high (24.0\%), and high (24.5\%) SES quartiles.

\section{Results}

In this section, the findings in relation to the three research questions and associated hypotheses are reported using tabular, graphical, and then multivariate analyses. The purpose of the analyses was to make simple empirical points about important 
patterns in the data and related determinants using micro-level data to probe important issues that were identified using macro-level data, as reported in Crouch and Merseth (2017).

\section{Enrollment in Primary 1: Under-Age, Target-Age, and Over-Age Students}

In relation to Research Question 1, the associated hypothesis tested was whether the proportion of under-age, target-age, and over-age students enrolled in Primary 1 differed among caregiver reports, school records (classroom register; head teacher register), and the official EMIS records. The percentage of learners in each age category was calculated according to source, tabulated, and the age distributions were compared graphically. As shown in Fig. 1, the hypothesis that caregiver reports of student age differed from school records was confirmed. Caregivers reported more over-age students, fewer target-age students, and more under-age students than official school record systems. Additionally, relatively few children were under-age for grade, despite anecdotal reports to the contrary.

Caregiver reports of the age at which they initially enrolled children in Primary 1 are displayed in Table 2 . This showed a much higher percentage of under-age students than was identified in the previous section (29\% vs. $11 \%)$. This is likely because early enrollees may repeat more often than 'on-targetage' enrollees. Of the total number of caregivers who enrolled their children in school early (before age 6 years; $n=347$ ), the most cited reason for sending their child early (36\%) was so that their child would learn. The most common reason that caregivers $(62 \%)$ cited for not enrolling their child in pre-primary education was financial considerations. Thus, the motivation for early enrollment in Primary 1 seems to be a desire to get the child started in some form of schooling and the lack of affordability of pre-primary education.

\section{Repetition of Primary 1 Students}

Whether higher rates for repetition of Primary 1 would be reported by caregivers and teachers for under-age or over-age students than the rates reported by schools to the Ugandan Government was also examined. As shown in Fig. 2, caregivers reported that $52 \%$ of students $(n=616)$ repeated Primary 1 , whereas teachers reported that $41 \%(n=572)$ were repeaters. Officially recorded data (classroom registers, head teacher registers, and EMIS records) showed lower levels of repetition, by up to a 41 percentage point difference.

Caregivers and teachers were also asked about their expectations of students' class enrollment for the following school year. More caregivers $(77 \%)$ than teachers $(57 \%)$ expected their children to progress to Primary 2 (see Table 3). Teachers reported that $41 \%$ of students could be expected to repeat Primary 1, a percentage that is very close to the reported repetition rate indicated by teachers. In general, it seemed that teachers expected children to repeat and reported such repetition occurring at about the same rate as per their expectation. 


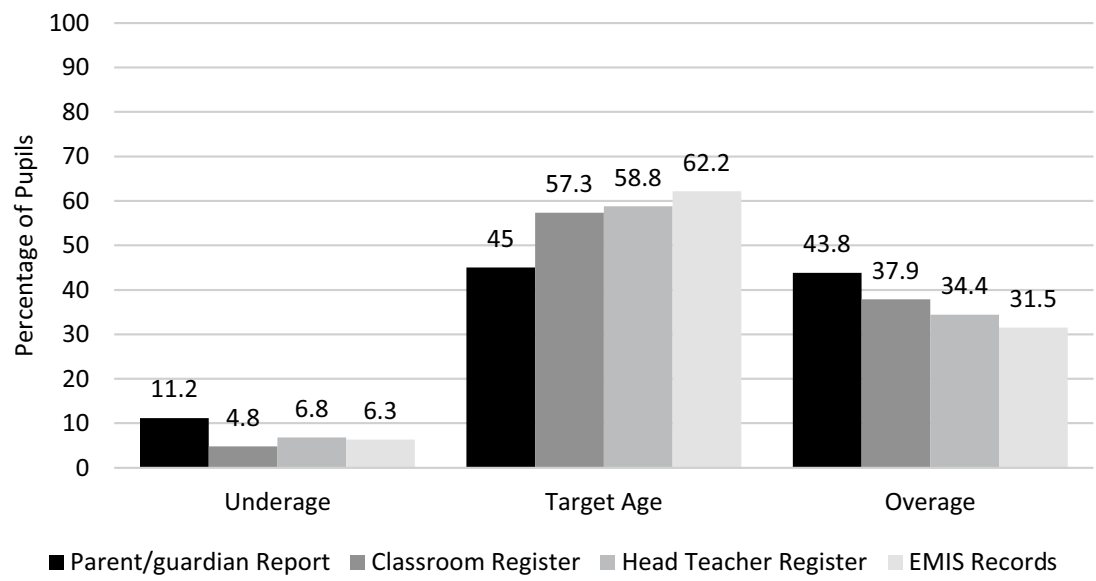

Fig. 1 Percentage of pupils in each age group by source. This figure shows age group calculations according to: caregiver report $(n=1318)$; classroom register $(n=11,575)$; head teacher records $(n=9660)$; and EMIS records $(n=10,330)$. Calculations of age group by class records involved calculating percentages across the total number of children at each age group across schools

Table 2 Age at which caregivers enrolled pupils in Primary 1

\begin{tabular}{llr}
\hline Age & Percentage & $n$ \\
\hline Under-age/age 5 or below & 29.4 & 359 \\
Target-age & 48.0 & 682 \\
Over-age/age 8 or above & 20.9 & 262 \\
Don't know & 1.7 & 15 \\
\hline
\end{tabular}

\section{Age of Students and Repetition of Primary 1}

To address the second research question on whether repetition in Primary 1 is serving as a pre-primary education substitute, we used t-tests to analyze for statistically significant differences in caregiver-reported ages of repeaters and non-repeaters, as well as simple one-way tabulations of reasons for sending children to school early. This research question also examined whether some caregivers used access to feefree Primary 1 instead of enrolling their child in pre-primary education. Figure 3 shows the age distribution of students who did, and did not repeat Primary 1.

On average, students who did not repeat Primary 1 were younger (mean age of 6.6 years) than students who repeated (mean age of 7.3 years) which was a statistically significant difference $(p=0.001)$. Although the expectation would be that repeaters would be one full year older than non-repeaters, the difference of 0.7 years indicates that students who repeat are likely to have been enrolled at an earlier than expected age for Primary 1. As previously noted, early enrollment in Primary 1 may take place because Primary 1 is free and caregivers may use it instead of fee-based pre-primary education. 


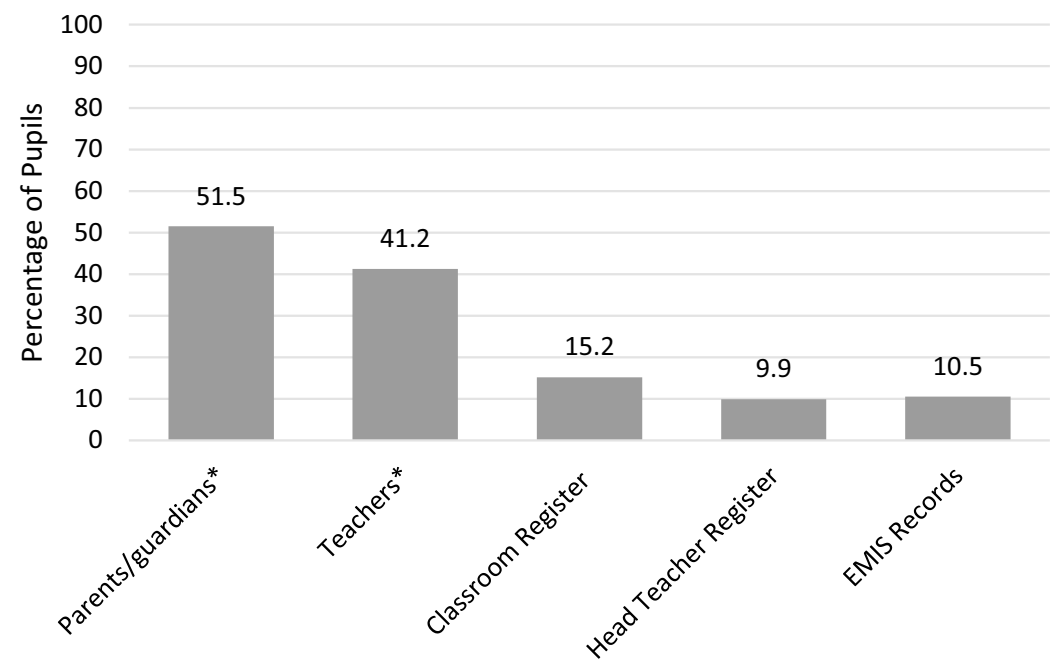

Fig. 2 Percentage of P1 students identified as repeaters, by source of information. Repetition data was collected from parents/guardians and teachers through interviews conducted at the school (2017); data from classroom and head teacher register were collected through a records review at the school (2017) and EMIS rates were provided by the Uganda MoES, based on 2016 school reporting

Table 3 Caregiver and teacher expectations about grade repetition for the following year

\begin{tabular}{llr}
\hline Expectation & Percentage & $N$ \\
\hline Parents/guardians & & \\
Primary 1 (child is expected to repeat Primary 1) & 19.4 & 1059 \\
Primary 2 (child will progress to next grade) & 77.1 & \\
Teachers & & 568 \\
Primary 1 (pupil is expected to repeat Primary 1) & 40.9 & 844 \\
Primary 2 (pupil will progress to Primary 2) & 57.1 & \\
\hline
\end{tabular}

More than half of all caregivers (56\%) who sent their child to school early responded that they knew the child would be likely to repeat Primary 1 as a result. Additionally, $61 \%$ of caregivers also responded that they expected their child might learn less in the first year of Primary 1 because of early enrollment. When asked for the reason their child did not attend pre-primary education, $62 \%$ of caregivers responded that they could not afford it. The data points in Fig. 3 indicate a pattern of early enrollment reported by a considerable proportion of caregivers, with the expectation of repetition being driven by cost considerations. 


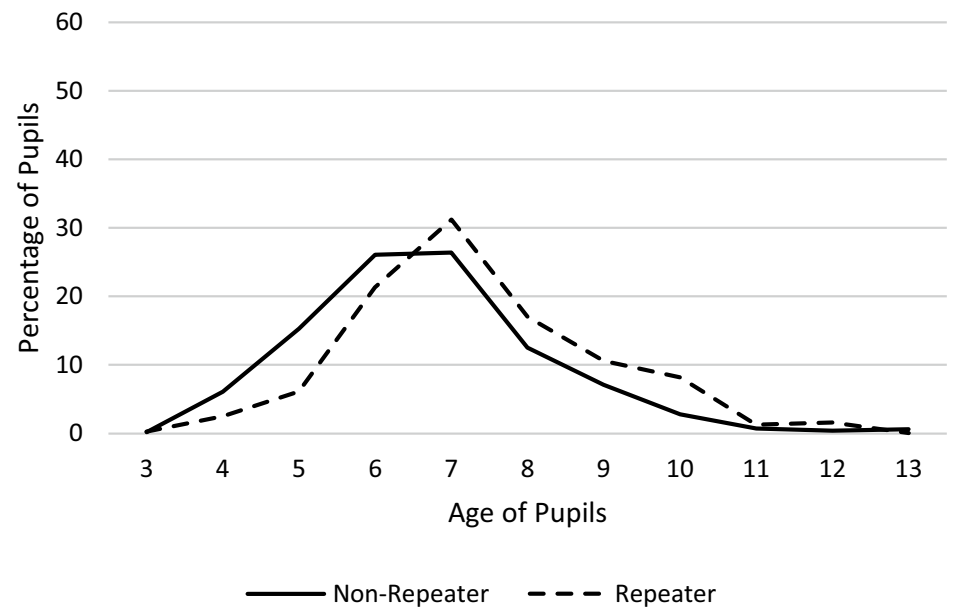

Fig. 3 Age in years, by repeater status, caregiver-reported through school-level interviews, 2017

\section{Pre-primary Participation and Primary 1 Repetition}

The third research question examined whether pupils who were exposed to some form of pre-primary education were less likely to repeat Primary 1 . It also investigated the relationship between repetition, age, and participation in pre-primary education using two-way tabular analysis with significance testing, as well as through logistic regression. All variables included in these analyses were measured through caregiver report.

From caregiver reports, $34 \%$ of students attended some form of pre-primary education prior to enrollment in Primary 1. The data depicted in Fig. 4 shows that 63\% of students who did not attend pre-primary education were likely to repeat Primary 1 compared to $29 \%$ of students whose caregivers reported participation in pre-primary.

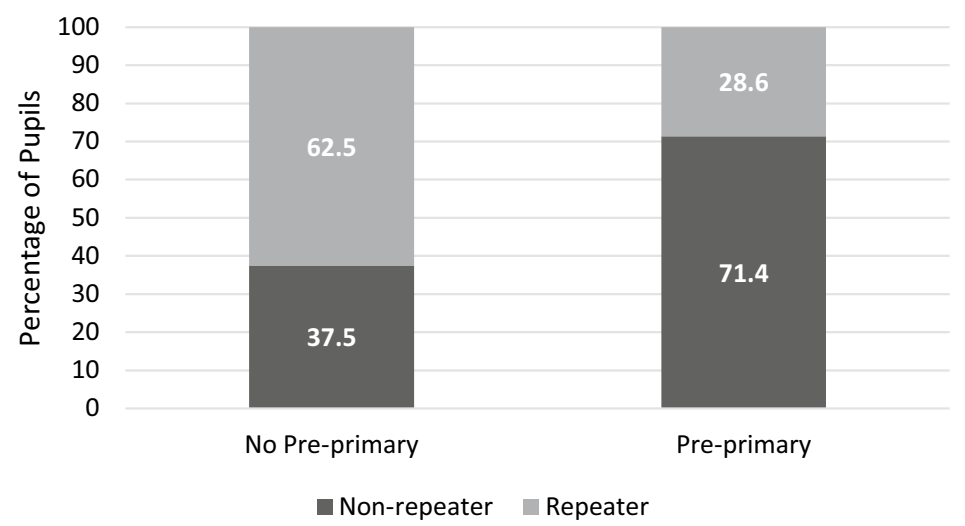

Fig. 4 Distribution of repeaters and non-repeaters in Primary 1, based on pre-primary attendance. This figure displays information collected through caregiver interviews, 2017 
To more carefully examine the hypothesis that pupils who were exposed to preprimary education were less likely to repeat Primary 1 , we used logistic regression. A logistic regression provided an appropriate way to identify the association between repetition of Primary 1 and exposure to pre-primary education, while controlling for other influencing variables. In logistic regression analysis, the estimation of the $\log$ odds for repeating Primary 1, given no exposure to pre-primary education, could be obtained. Other control variables in the logistic regression model included gender, age of enrollment, SES, and reported disability. The results of the logistic regression are presented in Table 4. These results show that students who did not attend a pre-primary program had 3.8 times higher odds for repeating Primary 1 than those students who had participated in pre-primary education. Although without an experimental or quasi-experimental design, causality cannot be directly inferred, this finding suggests a strong effect. Another significant variable in the logistic regression analyses, as indicated in Table 4, was that students who were under-age at enrollment were also more likely to repeat Primary 1 (1.65 higher odds for repeating than those students who enrolled at target-age).

\section{Discussion}

The purpose of this study was to examine factors related to over-enrollment in Uganda by investigating hidden repetition rates for attendance in Primary 1, including examining age of students and enrollment in Primary 1 as a substitute for

Table 4 Logistic regression model to identify factors driving repetition

\begin{tabular}{llll}
\hline Determining factor & \multicolumn{2}{l}{ Repetition } & \\
\cline { 2 - 4 } & Odds ratio & Coeff (SE) & Confidence intervals \\
\hline $\begin{array}{l}\text { No exposure to pre-primary } \\
\text { Pre-primary attended (reference) }\end{array}$ & $3.8^{* * *}$ & 0.87 & $2.37-6.18$ \\
Girl & 0.74 & 0.12 & $0.52-1.05$ \\
Boy (reference) & & & \\
Under-age at enrollment & $1.65^{* *}$ & 0.26 & $1.18-2.31$ \\
Over-age at enrollment & 0.79 & 0.10 & $0.61-1.03$ \\
Target-age at enrollment (reference) & & & $0.86-1.80$ \\
Lowest quartile SES & 1.2 & 0.22 & $0.69-1.49$ \\
Mid-low SES & 1.01 & 0.18 & $0.45-1.25$ \\
Mid-high SES & 0.75 & 0.18 & $1.25-3.6$ \\
High SES (reference) & & & \\
Disability (caregiver-reported) & $2.11^{* *}$ & 0.52 & $0.30-0.62$ \\
No disability reported (reference) & & & \\
Intercept & 0.43 & 0.07 & \\
\hline
\end{tabular}

${ }^{* *} p<.01 ; * * *<.001$ 
participation in pre-primary education and whether attending pre-primary affected repetition.

Our study yielded five findings in relation to the research questions: First, a large proportion of the children attending Primary 1 were over-age. This held true across data sources, with caregivers reporting 44\%, and school record reports ranging from 32 to $38 \%$. Second, repetition rates, as perceived and reported by caregivers and teachers, were much higher than officially reported to the MoES. Caregiver reports suggested that $52 \%$ of students were repeating, as compared to much lower rates found on classroom registers (15\%), head teacher records (10\%), and EMIS forms (11\%). Third, children who had repeated were only 0.7 years older than those who did not repeat, and children who had not participated in pre-primary education were much younger at entry into Primary 1 than children who had participated in pre-primary. Caregivers often enrolled their children in Primary 1 instead of pre-primary due largely to affordability, even when they knew that this meant that the children would likely repeat. Fourth, pre-primary education played a protective role against repetition. Children who do not have pre-primary exposure had 3.8 times greater odds of repeating Primary 1, even after controlling for SES and other variables.

These findings contribute to the growing body of research on the relationship between participation in pre-primary education and improved primary education outcomes (Jarmillo and Tietjen 2001; Lockheed and Verspoor 1992; Rao et al. 2014). Finally, the findings suggest that the data reported to the MoES and recorded at the school level, on these critical variables, are largely inaccurate. Although misreporting of data is not a new problem, these results are similar to other earlier studies that highlight systemic challenges in collecting reliable and valid data in other regions of the world (Cuadra and Ewert 1987; Klein and Ribeiro 1991).

The current study has a number of limitations. First, complete school records were not always available for review at the school. Although only $2 \%$ of the sample of schools had no records at all, a more accurate representation of age and repetition rates from school records would be ideal, and gaps in records may be considered a finding in itself. It is possible that some school leaders were reluctant to hand over records tantamount to admitting they were disregarding age and repetition policies, but some records were simply incomplete. Secondly, the current study did not include information on student outcomes either in pre-primary or Primary 1, or about the quality of the learning environments. Examining relationships between quality of pre-primary, quality of Primary 1, and then repetition, would provide a more comprehensive view of inefficiency issues affecting the school system. Finally, though it is possible that there could be additional factors that our multivariate model did not include as control variables in the regression analyses, the model indicated, by the size of the odds ratio, a strong association between repetition and lack of pre-primary participation.

The inefficiency of Uganda's primary school system is characterized by a gross enrollment ratio that is much higher than the completion rate for primary school, by about 50 percentage points, or nearly double the completion rate. In line with existing research that points to these leading causes of inefficiencies (Bernard et al. 2007; Kabay 2016), this suggests that there is close to two years of effort and resources lost within the system for every grade completed, because of repetition and dropout. 
However, data in the pilot study for this current study (Brunette et al. 2017) also showed that the greatest bulge of over-enrollment takes place in the early primary grades, in particular, Primary 1. Dropout is limited mainly to the upper grades of primary school. This suggests a pattern of early repetition could negatively impact on opportunities to deliver quality programs with developmentally appropriate instruction, as well as the impact of overcrowded classrooms. This pattern may lead to student disenchantment and dropout, which further contribute to inefficiencies in the school system.

From other research, we know that the quality of teaching and learning in Primary 1 through Primary 3 is very low. For example, the Uwezo (2016) assessment of learning in Ugandan schools found that among students in Primary 3-7, only 3 out of 10 students could read a Primary 2 level story or perform Primary 2 level mathematical division. The Early Grade Reading Assessment conducted in Uganda in 2010 concluded that more than half of children could not read any words in a set reading passage by the end of Grade 2 (Crouch and Kibombo 2015). This suggests that the bottlenecks that result by having to invest close to 2 years of schooling for every grade of achievement begins at the foundation stages of the education system. Improving performance in the foundation years of education, specifically by provision of free pre-primary education, could contribute to higher rates of primary school completion. Financial simulation models also suggest that even if improving the quality of the foundation year of primary schooling to improve performance required higher costs per child, this may still result in lower costs per completer of the primary school cycle overall (Weatherholt et al. 2018). This would occur because of reduction in grade repetition and subsequent dropout and also by increasing caregivers' confidence that their children are learning at school.

\section{Conclusions}

Further research could explore more ideal ways to provide pre-primary care and education in Uganda, as well as in other countries that experience similar patterns of early over-enrollment, as well as lower levels of primary school completion. Future research could focus on: (1) how to link and conceptualize "quality" and the learning expectations for pre-primary education and the early grades of school so that there is continuity across those systems; (2) how to set a clear policy that is consistent and progressive between pre-primary and the early years of primary school; and (3) how to prevent "fade-out" effects from quality improvements in the foundational years, as children progress through to the upper grades of primary school. However, the highest-level policy implications of this research, and related studies, is that Uganda and other countries with this pattern of over-enrollment could produce higher rates of primary school completions at lower costs per completer if over-enrollment was managed more carefully and adroitly than is evident in current practices that have resulted in high over-enrollment in the early years of school. 
Acknowledgements This work was supported by the UK Aid, Department of International Development (DFID), East African Research Fund [Contract Number: EARF/ITT/019]. A co-author of the manuscript is also an employee of DFID as the in-country contracting officer.

Open Access This article is distributed under the terms of the Creative Commons Attribution 4.0 International License (http://creativecommons.org/licenses/by/4.0/), which permits unrestricted use, distribution, and reproduction in any medium, provided you give appropriate credit to the original author(s) and the source, provide a link to the Creative Commons license, and indicate if changes were made.

\section{References}

Amadio, M. (1996). Primary school repetition: A global perspective. Paris: UNESCO International Bureau of Education. Retrieved on March 1, 2018 from http://unesdoc.unesco.org/image s/0014/001493/149393eo.pdf.

Bartlett, S., Pradhanang, U., Sapkota, P., \& Thapa, N. (2004). Everyone counts: Dalit children and the right to education in Nepal. Kathmandu, Nepal: Save the Children. Retrieved on March 1, 2018 from http://cergnyc.org/files/2011/09/Dalit-mar-41.pdf.

Berlinski, S., Galiani, S., \& Gertler, P. (2006). The effect of pre-primary education on primary school performance. London, Buenos Aires, Washington DC: University College London, Institute for Fiscal Studies, Universidad de San Andres and World Bank.

Bernard, J. M., Simon, O., \& Vianou, K. (2007). Repeating: An African school mirage. Prepared for the conference of ministers of education in countries sharing the French language (CONFEMEN), programme for the analysis of education systems (PASEC). Dakar: CONFEMEN Permanent Technical Secretariat.

Branson, N., Hofmeyr, C., \& Lam, D. (2013). Progress through school and the determinants of school dropout in South Africa. Development Southern Africa, 31, 106-126. https://doi.org/10.1080/03768 35X.2013.853610.

Brunette, T., Crouch, L., Cummiskey, C., Dick, A., Henny, C., Jordan, R., et al. (2017). Repetition of primary 1 and pre-primary education in Uganda. Research Triangle Park, NC: RTI Press. Retrieved from https://www.rti.org/publication/repetition-primary-1-and-pre-primary-education-uganda.

Crouch, L, \& Kibombo, R. (2015). Foundational first five years of education: Lessons from the data, cost to the system, and approaches to improve-Technical background. Presented at the national forum on the State of the Ugandan Child. Munyonyo, Uganda.

Crouch, L., \& Merseth, K. (2017). Stumbling at the first step: Efficiency implications of poor performance in the foundational first five years. Prospects. https://doi.org/10.1007/s11125-017-9401-1.

Cuadra, E., \& Ewert, G. (1987). Comparison of school records with parents' information of enrollment, repetition, and dropout: A field study in Honduras. Project Bridges: Harvard University.

Ejuu, G. (2012). The status of implementation of the education sector early childhood development policy in Uganda. Report submitted to Uganda National Commission for UNESCO: Kampala, Uganda. Retrieved on March 1, 2018 from http://www.education.go.ug/files/downloads/Early\%20Childhoo d\%20Development\%20Policy\%20Review.pdf.

Filmer, D., \& Pritchett, L. H. (2001). Estimating wealth effects without expenditure data-Or tears: An application to educational enrollments in states of India. Demography, 38, 115-132.

Gargiulo, C., \& Crouch, L. (1994). Nicaragua: Escolaridad, repetición y deserción escolar: Resultados de una encuesta nacional. Prepared for USAID/Washington. Research Triangle Park, NC: RTI International.

Gibbs, B. G., \& Heaton, T. B. (2014). Drop out from primary to secondary school in Mexico: A life course perspective. International Journal of Educational Development, 36, 63-71. https://doi. org/10.1016/j.ijedudev.2013.11.005.

Jarmillo, A., \& Tietjen, K. (2001). Early childhood development in Africa-Can we do more for less? A look at the impact and implications of preschools in Cape Verde and Guinea. Africa Region Human Development working paper series; Africa regional educational publications. Washington, DC: World Bank.

Kabay, S. (2016). Grade repetition and primary school dropout in Uganda. Harvard Educational Review, 86, 580-606. https://doi.org/10.17763/1943-5045-86.4.580. 
King, K., \& Meyers, R. (1983). Preventing school failure: The relationship between preschool and primary education. Ottawa: International Development Research Center.

Klein, R., \& Ribeiro, S. C. (1991). O censo educacional e o modelo de fluxo: O problema da repetência. Revista Brasileira de Estatística, 52, 5-45.

Lockheed, M., \& Verspoor, A. M. (1992). Improving primary education in developing countries. New York: Oxford University Press.

Lockheed, M. E., \& Hanushek, E. (1994). Concepts of educational efficiency and effectiveness. Human Resources Development and Operations Policy. Working paper series. HRO working papers HROWP 24. Washington, DC: World Bank.

Ministry of Education and Sports [Uganda]. (2015). Education statistical abstract 2015. Kampala: Author. Retrieved on March 1, 2018 from http://www.education.go.ug/files/downloads/Abstract\%202015.pdf.

Mosteller, F. (1995). The Tennessee study of class size in the early school grades. The Future of Children, 5, 113-127. https://doi.org/10.2307/1602360.

N'tchougan-Sonou, C. H. (2001). Automatic promotion or large-scale repetition-Which path to quality? International Journal of Educational Development, 21, 149-162. https://doi.org/10.1016/s0738 $-0593(00) 00016-\mathrm{x}$.

Okuni, A. (2003). EFA policies, strategies and reforms in Uganda: Assessment of the current potential for sustainable progress toward achieving the EFA goals by 2015. Paper commissioned for the EFA global monitoring report 2003/4. The Leap to Equality, Paris: UNESCO.

Rao, N., Sun, J., Wong, J. M. S., Weekes, B., Ip, P., Shaeffer, S., et al. (2014). Early childhood development and cognitive development in developing countries: A rigorous literature review. Hong Kong: Department for International Development.

Reimers, F. (1993). The challenges for early childhood education policy in Latin America and the Caribbean. International Journal of Educational Development, 13, 303-314. https://doi. org/10.1016/0738-0593(93)90042-X.

Sabates, R., Hossain, A., \& Lewin, K. M. (2013). School drop out in Bangladesh: Insights using panel data. International Journal of Educational Development, 33, 225-232. https://doi.org/10.1016/j. ijedudev.2012.09.007.

Sandefur, J., \& Glassman, A. (2014). The political economy of bad data: Evidence from African survey and administrative studies. Working paper 373. Washington D.C.: Center for Global Development.

Save the Children. (2004). Early childhood care and development: A positive impact. Yangon, Myanmar: Save the Children Myanmar Field Office. Retrieved on March 1, 2018 from http://www.unicef.org/ earlychildhood/index_resources.html.

Smith, M., \& Barrett, A. M. (2010). Social and economic effects on primary pupils' reading achievement: Findings from Southern and East Africa. EdQual working paper. Bristol, UK: EdQual.

Smith, M. L. (1989). Teachers' beliefs about retention. In L. A. Shepard \& M. L. Smith (Eds.), Flunking grades: Research and policies on retention (pp. 132-150). London: Falmer Press.

UNESCO Institute for Statistics. (2012). Stumbling blocks to universal primary education: Repetition rates decline but dropout rates remain high. Paris: UNESCO Institute for Statistics.

UNESCO Institute for Statistics. (2016). Primary school enrollment, Uganda 2016 [data file]. Paris: UNESCO Institute for Statistics. Retrieved on March 1, 2018 from https://data.worldbank.org/indic ator/SE.PRM.ENRR?locations=UG\&view =chart.

Uwezo. (2016). Are Our Children Learning? Uwezo Uganda 6th learning assessment report. Kampala, Uganda: Twaweza East Africa. Retrieved on February 27, 2019 from http://www.uwezo.net/wpcontent/uploads/2016/12/UwezoUganda2015ALAReport-FINAL-EN-web.pdf.

Van der Berg, S. (2008). How effective are poor schools? Poverty and educational outcomes in South Africa. Studies in Educational Evaluation, 34, 145-154.

Weatherholt, T., Nabacwa, R., Crouch, L., Pressley, J., Jordan, R., Healey, H., et al. (2018). Uganda early years enrolment and repetition study. Report submitted to UK AID Department of International Development.

Yu, G., \& Thomas, S. M. (2008). Exploring school effects across southern and eastern African school systems and in Tanzania. Assessment in Education: Principles, Policy, \& Practice, 15, 283-305. https://doi.org/10.1080/09695940802417525.

Publisher's Note Springer Nature remains neutral with regard to jurisdictional claims in published maps and institutional affiliations. 